\title{
Formation of bromate and halogenated disinfection byproducts during chlorination of bromide-containing waters in the presence of dissolved organic matter and $\mathrm{CuO}$ \\ Chao Liu, and Jean-Philippe Croue
}

Environ. Sci. Technol., Just Accepted Manuscript • DOI: 10.1021/acs.est.5b03266 • Publication Date (Web): 02 Dec 2015

Downloaded from http://pubs.acs.org on December 8, 2015

\section{Just Accepted}

\begin{abstract}
"Just Accepted" manuscripts have been peer-reviewed and accepted for publication. They are posted online prior to technical editing, formatting for publication and author proofing. The American Chemical Society provides "Just Accepted" as a free service to the research community to expedite the dissemination of scientific material as soon as possible after acceptance. "Just Accepted" manuscripts appear in full in PDF format accompanied by an HTML abstract. "Just Accepted" manuscripts have been fully peer reviewed, but should not be considered the official version of record. They are accessible to all readers and citable by the Digital Object Identifier (DOI®). "Just Accepted" is an optional service offered to authors. Therefore, the "Just Accepted" Web site may not include all articles that will be published in the journal. After a manuscript is technically edited and formatted, it will be removed from the "Just Accepted" Web site and published as an ASAP article. Note that technical editing may introduce minor changes to the manuscript text and/or graphics which could affect content, and all legal disclaimers and ethical guidelines that apply to the journal pertain. ACS cannot be held responsible for errors or consequences arising from the use of information contained in these "Just Accepted" manuscripts.
\end{abstract}


1 Formation of bromate and halogenated disinfection byproducts

2 during chlorination of bromide-containing waters in the presence of dissolved organic matter and $\mathrm{CuO}$

4

5

*Corresponding author: Tel.: +1-864-656-3276; Fax: +1-864-656-0672; E-mail:

chao.liu@kaust.edu.sa; chao2@,clemson.edu

$\perp$ Current Address: Department of Environmental Engineering and Earth Sciences, Clemson University, Anderson, South Carolina 29625, United States 


\section{Abstract}

17 Previous studies showed that significant bromate $\left(\mathrm{BrO}_{3}{ }^{-}\right)$can be formed via the CuO-catalyzed

18 disproportionation of hypobromous acid ( $\mathrm{HOBr}$ ) pathway. In this study, the influence of $\mathrm{CuO}$ on

19 the formation of $\mathrm{BrO}_{3}{ }^{-}$and halogenated disinfection byproducts (DBPs) (e.g., trihalomethanes,

20 THMs and haloacetic acids, HAAs) during chlorination of six dissolved organic matter (DOM)

21 isolates was investigated. Only in the presence of slow reacting DOM (from treated Colorado

22 River water, i.e., CRW-BF-HPO), significant $\mathrm{BrO}_{3}{ }^{-}$formation is observed, which competes with

23 bromination of DOM (i.e., THM and HAA formation). Reactions between HOBr and 12 model

24 compounds in the presence of $\mathrm{CuO}$ indicates that $\mathrm{CuO}$-catalyzed $\mathrm{HOBr}$ disproportionation is

25 completely inhibited by fast reacting phenols, while it predominates in the presence of practically

26 unreactive compounds (acetone, butanol, propionic, and butyric acids). In the presence of slow

27 reacting di- and tri-carboxylic acids (oxalic, malonic, succinic, and citric acids), $\mathrm{BrO}_{3}{ }^{-}$formation

28 varies, depending on its competition with bromoform and dibromoacetic acid formation (i.e.,

29 bromination pathway). The latter pathway can be enhanced by $\mathrm{CuO}$ due to the activation of

$30 \mathrm{HOBr}$. Therefore, increasing $\mathrm{CuO}$ dose $\left(0-0.2 \mathrm{~g} \mathrm{~L}^{-1}\right)$ in a reaction system containing chlorine,

31 bromide, and CRW-BF-HPO enhances the formation of $\mathrm{BrO}_{3}{ }^{-}$, total THMs and HAAs. Factors

32 including $\mathrm{pH}$ and initial reactant concentrations influence the DBP formation. These novel

33 findings have implications for elevated DBP formation during transportation of chlorinated

34 waters in copper-containing distribution systems. 


\section{- Introduction}

37 Distribution systems are the final barriers for drinking water before delivery to the taps of consumers. A generally used strategy to control microbial contaminants and bacterial growth and to improve the hygienic drinking water quality in distribution systems is to maintain a residual oxidant. Among various oxidants, chlorine is the most used chemical oxidant for residual $41 \quad$ protection. ${ }^{1}$

While chlorine disinfection provides hygienically safe drinking water, chlorine (in the form of hypochlorous acid, i.e., $\mathrm{HOCl}$, in water) also reacts with dissolved organic matter (DOM) to 44 produce potentially toxic chlorinated disinfection byproducts (DBPs). Among various DBPs, the most recognized compounds are trihalomethanes (THMs) and haloacetic acids (HAAs). ${ }^{2-7}$ In the presence of bromide $\left(\mathrm{Br}^{-}\right), \mathrm{HOCl}$ can rapidly oxidize naturally occurring $\mathrm{Br}^{-}$to hypobromous acid $(\mathrm{HOBr}) .{ }^{8}$ Upon the reaction between $\mathrm{HOCl} / \mathrm{HOBr}$ and DOM, four THMs (i.e., THM4, sum of $\mathrm{CHCl}_{3}, \mathrm{CHBrCl}_{2}, \mathrm{CHBr}_{2} \mathrm{Cl}$, and $\mathrm{CHBr}_{3}$ ) and nine HAAs (i.e., HAA9, sum of monochloro-, dichloro-, trichloro-, monobromo-, dibromo-, bromochloro-, bromodichloro-, dibromochloro-, and tribromo-acetic acids (MCAA, DCAA, TCAA, MBAA, DBAA, BCAA, BDCAA, DBCAA, 51 and TBAA, respectively)) can be formed. ${ }^{6,9-11}$ THM4 and HAA5 (sum of MCAA, DCAA, 52 TCAA, MBAA, and DBAA) are currently regulated for drinking water at $80 \mu \mathrm{g} \mathrm{L}^{-1}$ and $60 \mu \mathrm{g} \mathrm{\textrm {L } ^ { - }}$

$53{ }^{1}$ by the U.S. Environmental Protection Agency (US EPA), respectively ${ }^{12}$. These DBPs are also 54 fully or partly regulated in drinking water in other countries (e.g., European Union ${ }^{13}$, China ${ }^{14}$ ).

55 Unlike ozone which can further oxidize $\mathrm{HOBr}$ to potentially toxic bromate $\left(\mathrm{BrO}_{3}{ }^{-}\right),{ }^{15-17}$ the 56 rate constant for the reaction between $\mathrm{HOCl}$ and $\mathrm{HOBr}$ is low. ${ }^{18}$ Therefore, $\mathrm{BrO}_{3}{ }^{-}$formation 57 from chlorination of bromide-containing waters in water treatment is generally insignificant. 
Recently we showed that $\mathrm{CuO}$ can catalyze $\mathrm{HOX}(\mathrm{X}$ : $\mathrm{Cl}$ or $\mathrm{Br})$ disproportionation to produce $\mathrm{X}^{-}$ and $\mathrm{XO}_{3}{ }^{-}$(eq 1 showing an example from $\left.\mathrm{HOBr}\right) .{ }^{19}$

61 It was reported that $\mathrm{CuO}$ is one of the major corrosion products of copper pipes that are widely

62

63

64

65

66

used in municipal distribution systems and household plumbing. ${ }^{20-23}$ This disproportionation pathway led to elevated $\mathrm{BrO}_{3}{ }^{-}$concentrations (e.g., $50 \mu \mathrm{g} \mathrm{L}{ }^{-1}$ ) exceeding the maximum contaminant level (i.e., MCL, $10 \mu \mathrm{g} \mathrm{L}^{-1}$ regulated by US EPA ${ }^{12}$ ) during chlorination of bromidecontaining waters in distribution systems. ${ }^{24}$ In addition, previous studies showed that $\mathrm{CuO}$ can enhance $\mathrm{HOCl} / \mathrm{HOBr}$ reactions with iodate to periodate and activate the reactivity of the other halogen-containing oxidant (e.g, $\left.\mathrm{ClO}_{2}\right){ }^{25,26}$

In the presence of $\mathrm{DOM}, \mathrm{HOBr}$ can react with organic moieties and thus $\mathrm{CuO}$-catalyzed disproportionation may be inhibited, shifting the DBP formation from inorganic (i.e., $\mathrm{BrO}_{3}{ }^{-}$) to halogenated organic species (e.g., THMs and HAAs). Previous studies showed that total THM formation was enhanced and the speciation of HAA was affected by the presence of $\mathrm{CuO}^{22,23}$ However, similar total HAA formation in the presence of $\mathrm{CuO}$ with that in the absence of $\mathrm{CuO}$ was further observed. ${ }^{27}$ Because of the variability of the results reported previously, it is still unclear if the reaction between $\mathrm{HOCl} / \mathrm{HOBr}$ and $\mathrm{DOM}$ can be enhanced by $\mathrm{CuO}$, leading to the elevated formation of both THM and HAA. Understanding how $\mathrm{CuO}$ will control the fate of bromine (i.e., $\mathrm{BrO}_{3}^{-}$versus brominated organics) during the transportation of chlorinated waters containing various types of DOM in distribution systems is therefore of major importance.

In view of the potential toxicological significance of the formation of regulated DBPs in drinking water, the objectives of this study were to investigate the formation and speciation of $\mathrm{BrO}_{3}{ }^{-}$, THMs and HAAs during chlorination of bromide-containing waters in the presence of 
81 DOM isolates and $\mathrm{CuO}$. Factors such as $\mathrm{pH}$, initial concentrations of $\mathrm{CuO}$, chlorine and $\mathrm{Br}^{-}$, as

82 well as the concentration and nature of DOM on DBP formation were studied. Furthermore, a

83 range of structurally diverse model compounds were selected to study the mechanism for the

84 formation of $\mathrm{BrO}_{3}{ }^{-}$, THMs and HAAs in the presence of $\mathrm{CuO}$.

\section{- Materials and methods}

87 Reagents. All chemical solutions were prepared from reagent grade chemicals or stock solutions using deionized water $(18.2 \mathrm{M} \Omega \cdot \mathrm{cm}$, Millipore). A sodium hypochlorite $(\mathrm{NaOCl})$ solution was used as the source of chlorine (13\% active chlorine, Acros Organics). CuO particles were prepared according to a previously published method. ${ }^{19}$ The BET surface areas were

91 determined by a Micromeritics Tristar II to be $33.7 \mathrm{~m}^{2} \mathrm{~g}^{-1}$. The $\mathrm{pH}_{\mathrm{pzc}}$ ( $\mathrm{pH}$ at which $\mathrm{CuO}$ particles

92 have a zero charge) was determined to be $8.6 .{ }^{28} \mathrm{HOBr}$ solutions were prepared by reaction of $93 \mathrm{NaOCl}$ with $\mathrm{Br}^{-19}$ The descriptions of all other standards and reagents used in this study are 94 provided in Text S1 of the Supporting Information (SI).

DOM Isolates and Selection of Model Compounds. Six previously isolated DOM fractions with the $\mathrm{SUVA}_{254}$ values (i.e., UV absorbance at $254 \mathrm{~nm}$ divided by the corresponding dissolved

97 organic carbon concentration) ranging from 1.1 to $4.9 \mathrm{~L} \mathrm{~m}^{-1} \mathrm{mg}^{-1}$ were used in this study (Table 98 S1, SI). Three hydrophobic DOM isolates, namely, CRW-PI1-HPO, CRW-F2E-HPO, and CRWBF-HPO were extracted from the influent of the water plant (Colorado River water, USA), 100 effluent after clarification (coagulation/flocculation/filtration) and biologically active filtration, 101 respectively. ${ }^{29}$ RRW-HPO, LRW-HPO, and SRW-HPOA were isolated from the Ribou 102 Reservoir (France), Loire River (France), and Suwannee River (Georgia, USA), respectively. As 
103 to better simulate drinking water distribution system condition, CRW-BF-HPO extracted from 104 plant effluent water was used as the DOM isolate throughout this study unless noted.

105 Three groups of model compounds representing functional moieties of DOM were selected, 106 including ketone, alcohol, mono-, di- and tri-carboxylic acids, and phenols. Structures and 107 physicochemical properties of model compounds are shown in Table S2 (SI).

108 Analytical methods. The analytical methods of residual oxidants, DOM characterization, 109 total organic carbon, total organic bromine (TOBr), $\mathrm{BrO}_{3}^{-}$, THMs, and HAAs can be found in 110 detail in Text S2 (SI).

111 Experimental setup and procedures. The influence of various drinking water parameters 112 including $\mathrm{CuO}$ dose, initial chlorine and $\mathrm{Br}^{-}$concentrations, $\mathrm{pH}$ and initial concentration and 113 type of DOM on the formation of $\mathrm{BrO}_{3}{ }^{-}$, THMs and HAAs was investigated. The $\mathrm{CuO}$ dose 114 ranged from 0 to $0.2 \mathrm{~g} \mathrm{~L}^{-1}$, based on our previous study to be able to investigate the reaction 115 kinetics in a selected time frame. ${ }^{19}$ Initial chlorine concentrations ranged from 14 to $70 \mu \mathrm{M}$ (i.e., 116 1.0-4.9 $\mathrm{mg} \mathrm{L}^{-1}$ as $\mathrm{Cl}_{2}$ ). Initial $\mathrm{Br}^{-}$concentrations varied from 0 to $10 \mu \mathrm{M}$ (i.e., 0-800 $\mu \mathrm{g} \mathrm{L}^{-1}$ ), 117 covering the typical $\mathrm{Br}^{-}$range in raw water. ${ }^{15}$ The $\mathrm{pH}$ was adjusted to 6.6, 7.6, 8.6 and 9.6 with $118 \mathrm{HNO}_{3}$ or $\mathrm{NaOH}$ solutions in the presence of a $2.5 \mathrm{mM}$ tetraborate buffer. The $\mathrm{pH}$ changes were 119 less than $0.2 \mathrm{pH}$ unit during the reaction. It should be noted that in most reaction conditions, a $120 \mathrm{pH}$ value of 8.6 that approaches the optimum $\mathrm{pH}$ for $\mathrm{HOBr}$ disproportionation was adopted to 121 better observe the $\mathrm{BrO}_{3}{ }^{-}$formation. ${ }^{19}$ DOM concentrations ranged from 0 to $20 \mathrm{mg} \mathrm{L}^{-1}$.

122 All experiments were conducted in the dark and under continuous agitation using a magnetic 123 stirrer in $250 \mathrm{~mL}$ capped amber bottles under headspace-free conditions at room temperature $124\left(21 \pm 1{ }^{\circ} \mathrm{C}\right)$. Reactions were initiated by the injection of an aliquot of a $\mathrm{HOCl} / \mathrm{HOBr}$ stock 125 solution, to the buffered solutions containing DOM or model compounds in the presence or 
126 absence of $\mathrm{CuO}$. Bromide was added when required. Samples were withdrawn at preselected 127 time points, filtered within 1-2 min through a $0.45-\mu \mathrm{m}$ syringe filter (surfactant-free cellulose 128 acetate membrane). The filter was pre-treated with $\mathrm{HOCl}$ or $\mathrm{HOBr}$ solutions $\left(1 \mathrm{mg} \mathrm{L}^{-1}\right)$ and then 129 rinsed with deionized water to avoid a potential oxidant demand. The filtered samples were 130 analyzed for residual oxidant concentrations. For the analyses of $\mathrm{BrO}_{3}{ }^{-}, \mathrm{THMs}$ and $\mathrm{HAAs}$, the 131 samples were quenched immediately with sulfite. Each experiment was performed in duplicate.

\section{- Results and discussion}

134 Effect of CuO dose and reaction time. Figure 1 shows concentrations of the residual 135 oxidant and formed $\mathrm{BrO}_{3}{ }^{-}$, THMs and HAAs for various $\mathrm{CuO}$ doses $\left(0-0.2 \mathrm{~g} \mathrm{~L}^{-1}\right)$. In the absence 136 of $\mathrm{CuO}, \mathrm{HOCl}$ and the formed $\mathrm{HOBr}$ react with $\mathrm{DOM}$, and $25 \%$ of initial oxidant was consumed 137 after $2 \mathrm{~h}$ reaction, leading to $107.7 \pm 6.5$ and $11.9 \pm 3.1 \mathrm{nM}$ for $\mathrm{THM} 4$ and total HAAs, 138 respectively. Because $\mathrm{HOCl}$ does not react with $\mathrm{HOBr},{ }^{18} \mathrm{BrO}_{3}{ }^{-}$concentration is low $\left(<1 \mu \mathrm{g} \mathrm{L}{ }^{-1}\right.$, 139 Figure 1a).

140 In the presence of $\mathrm{CuO}$, higher chlorine demands were observed. Increasing the $\mathrm{CuO}$ dose 141 led to a lower residual oxidant after $2 \mathrm{~h}$ reaction, almost complete oxidant consumption was 142 obtained with $0.2 \mathrm{~g} \mathrm{~L}^{-1} \mathrm{CuO}$. This can be ascribed to potential heterogeneous reactions of $143 \mathrm{HOCl} / \mathrm{HOBr}$ on the $\mathrm{CuO}$ surface (e.g., $\mathrm{HOCl} / \mathrm{HOBr}$ decay to oxygen, $\mathrm{HOCl} / \mathrm{HOBr}$ 144 disproportionation, and halogenation of DOM). ${ }^{19}$ Along with the fast oxidant loss, enhanced 145 concentrations of $\mathrm{BrO}_{3}{ }^{-}\left(5.7-29.9 \pm 1.5 \mu \mathrm{g} \mathrm{L}^{-1}\right)$ were formed in the presence of increasing $\mathrm{CuO}$ 146 doses from 0.05 to $0.2 \mathrm{~g} \mathrm{~L}^{-1}$, owning to the $\mathrm{CuO}$-catalyzed disproportionation of $\mathrm{HOBr}{ }^{19,24}$

147 Comparing with $\mathrm{BrO}_{3}{ }^{-}$, concentrations for bromine atom incorporated in THMs and HAAs 148 were higher (Figure S1, SI). This indicates that the $\mathrm{HOBr}$ reaction with DOM in the presence of 
$149 \mathrm{CuO}$ is the major pathway, while disproportionation is minor. The formation of THMs and 150 HAAs was enhanced as compared with reactions conducted in absence of $\mathrm{CuO}$ (Figure 1b-c). 151 Increasing the $\mathrm{CuO}$ doses from 0 to $0.2 \mathrm{~g} \mathrm{~L}^{-1}$ led to increasing total THM and HAA

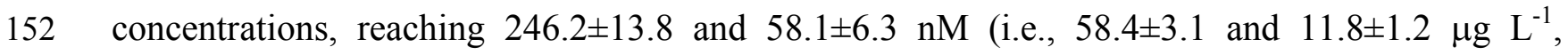
153 respectively) with $0.2 \mathrm{~g} \mathrm{~L}^{-1} \mathrm{CuO}$, which were 2.3 and 4.9 times higher than those in the absence 154 of $\mathrm{CuO}$, respectively.

155 Among the formed THMs and HAAs, $\mathrm{CHBr}_{3}(70.1-198.6 \mathrm{nM}$ ) and DBAA (up to $43.1 \mathrm{nM}$ ) 156 were the main species, respectively. $\mathrm{CHCl}_{3}, \mathrm{CHBrCl}_{2}$ and $\mathrm{CHBr}_{2} \mathrm{Cl}$ were detected at much lower 157 concentrations $(<26.8 \mathrm{nM})$. Similarly, DCAA, TCAA, and BCAA were detected at low levels $158(<10.4 \mathrm{nM})$. Tri-halogenated acetic acids (THAAs) were formed at much lower levels than di159 halogenated acetic acids (DHAAs). Only TCAA was detected $(<1.5 \mathrm{nM})$, and due to the limited 160 initial bromide concentration other brominated THAAs were not detected. This may be ascribed 161 to the limited THAA precursor in the studied DOM. It has been proposed that THAAs and 162 DHAAs can have different precursors. ${ }^{30}$

163 Figure S2 (SI) shows that the DOM concentration is stable in the presence of $0.1 \mathrm{~g} \mathrm{~L}^{-1} \mathrm{CuO}_{\text {, }}$ 164 even for long reaction times (a few days), indicating that there is no significant adsorption of 165 DOM (i.e., $\mathrm{CRW}-\mathrm{BF}-\mathrm{HPO})$ to $\mathrm{CuO}$. Previous studies indicated that $\mathrm{CuO}$ can adsorb $166 \mathrm{HOCl} / \mathrm{HOBr}$ to form a $\mathrm{CuO}-\mathrm{HOCl} / \mathrm{CuO}-\mathrm{HOBr}$ complex, thereby activating the reactivity of $167 \mathrm{HOCl} / \mathrm{HOBr}$ towards several inorganic species (e.g., chlorine, bromine, iodine, and iodate). ${ }^{19,24,}$ $168{ }^{26} \mathrm{By}$ analogy, it is proposed that in the presence of DOM the formed $\mathrm{CuO}-\mathrm{HOCl} / \mathrm{CuO}-\mathrm{HOBr}$ 169 complex showed a higher reactivity towards the slow reacting moieties of DOM, thus enhancing 170 the formation of THMs and HAAs. Interestingly, increasing $\mathrm{CuO}$ dose from 0 to $0.2 \mathrm{~g} \mathrm{~L}^{-1}$ 171 significantly enhanced the formation of brominated species (e.g., $\mathrm{CHBr}_{3}$ and $\mathrm{DBAA}$ ) and 
172 bromine atom incorporated in THMs and HAAs. However, the enhancement for the formation of 173 chlorinated species and chlorine atom incorporated in THMs and HAAs was less significant 174 (Figure $1 \mathrm{~b}$-c, Figure $\mathrm{S} 1, \mathrm{SI}$ ). This might indicate that $\mathrm{CuO}$ is more prone to activate the reactivity 175 of $\mathrm{HOBr}$ than $\mathrm{HOCl}$ at $\mathrm{pH} 8.6$, which was also observed for the $\mathrm{HOCl} / \mathrm{HOBr}$ reactions with 176 iodate in the presence of $\mathrm{CuO}^{26}$ Our results agree with a previous investigation showing 177 enhanced THM formation in the presence of $\mathrm{CuO}^{23}$ However, the fact that another study 178 reported similar HAA formation in the presence and absence of $\mathrm{CuO}$ might be ascribed to the 179 low $\mathrm{Br}^{-}$dose used $(0.8 \pm 0.2 \mu \mathrm{M}),{ }^{27}$ which minimized the enhancement of the reaction since $180 \mathrm{HOBr}$ is more readily activated by $\mathrm{CuO}$ than $\mathrm{HOCl}$.

181 During the chlorination process, bromine species includes $\mathrm{Br}^{-}, \mathrm{HOBr}, \mathrm{BrO}_{3}{ }^{-}$, and $\mathrm{TOBr}$. 182 Concentrations of $\mathrm{BrO}_{3}{ }^{-}$and $\mathrm{TOBr}$ in the presence of $0.1 \mathrm{~g} \mathrm{~L}^{-} \mathrm{CuO}$ were measured to be 0.2 and $1831.5 \pm 0.2 \mu \mathrm{M}$, respectively. Due to analytical restrictions in measuring $\mathrm{Br}^{-}$and residual $\mathrm{HOBr}$ in 184 tetraborate-buffered chlorinated solutions, the total mass balance of bromine species cannot be 185 calculated. However, if an initial $\mathrm{Br}^{-}$concentration of $10 \mu \mathrm{M}$ is considered, $\mathrm{Br}^{-}$and $\mathrm{HOBr}$ were 186 the main bromine species $(>83 \pm 2 \%)$ present at $2 \mathrm{~h}$. Furthermore, based on residual oxidant 187 concentration and second-order rate constant between $\mathrm{HOCl}$ and $\mathrm{Br}^{-}\left(\mathrm{k}=1550 \mathrm{M}^{-1} \mathrm{~s}^{-1}\right){ }^{8}$ it can be 188 estimated that $\mathrm{HOBr}$ predominates at $2 \mathrm{~h}$. Since chlorine concentration tends to be lower, the 189 recycling of $\mathrm{Br}^{-}$to $\mathrm{HOBr}$ becomes less important, leading to a lower yield of formation of $\mathrm{BrO}_{3}^{-}$ 190 and brominated DBPs.

191 Figure S3 (SI) shows concentrations of residual oxidant and formed $\mathrm{BrO}_{3}{ }^{-}$, $\mathrm{THMs}$, and 192 HAAs at different reaction times (i.e., ranging from $2 \mathrm{~h}$ to $12.7 \mathrm{~h}$ ). Since the oxidant decays 193 faster at higher $\mathrm{CuO}$ doses (e.g., $0.2 \mathrm{~g} \mathrm{~L}^{-1}$ ), a $\mathrm{CuO}$ dose of $0.025 \mathrm{~g} \mathrm{~L}^{-1}$ was selected to allow the 194 reactions for longer time $(>12 \mathrm{~h})$. After $12.7 \mathrm{~h}$ reaction, the residual oxidant concentration was 
$1952.8 \pm 0.3 \mu \mathrm{M}$, corresponding to a 93\% oxidant consumption. From 2 to $8 \mathrm{~h}, \mathrm{BrO}_{3}{ }^{-}, \mathrm{THM} 4$ and 196 total HAA concentrations increased by 217.6, 231.7, and 27.1 nM, respectively. However, from 1978 to $12.7 \mathrm{~h}$ the increase was $194.1,27.1$, and $2.4 \mathrm{nM}$ for $\mathrm{BrO}_{3}{ }^{-}$, THM4 and total HAAs, 198 respectively. Comparable $\mathrm{BrO}_{3}{ }^{-}$formation but significantly less halogenated DBP formation in 199 the latter time range indicates that the disproportionation pathway outcompetes the halogenation 200 pathway. DOM consists of fast reacting and slow reacting/unreactive moieties, leading to the 201 two-stage reaction kinetics (i.e., rapid initial and slower consumption stages) for chlorination or 202 bromination of DOM isolates. ${ }^{6}$ After the degradation of fast reacting DOM moieties, the rate 203 constant for the reaction of $\mathrm{HOBr}$ disproportionation catalyzed by $\mathrm{CuO}$ was higher than that for 204 the reaction between $\mathrm{HOBr}$ and slow reacting $\mathrm{DOM}$ moieties. $\mathrm{BrO}_{3}{ }^{-}$formation becomes 205 important in the slower oxidant consumption stage. oxidant and formed $\mathrm{BrO}_{3}{ }^{-}$, THMs and HAAs for various initial chlorine concentrations (14-70 $209 \mu \mathrm{M}$, i.e., 1.0-4.9 $\mathrm{mg} \mathrm{L}^{-1}$ ). Increasing the initial chlorine concentration led to an increasing 210 residual oxidant from 0 to $29.6 \pm 2.0 \mu \mathrm{M}$, with an increasing $\mathrm{BrO}_{3}{ }^{-}$formation (0 to 1.2 $\pm 0.2 \mu \mathrm{M}$, 211 i.e., 0 to $146.5 \pm 20.5 \mu \mathrm{g} \mathrm{L}^{-1}$ ). As above mentioned, the CuO-catalyzed disproportionation of $212 \mathrm{HOBr}$ which is formed from the recycling of $\mathrm{Br}^{-}$by $\mathrm{HOCl}$ will outcompete the $\mathrm{HOBr}$ reaction 213 with slow reacting/unreactive DOM moieties at higher $\mathrm{Cl}_{2} / \mathrm{DOM}$, leading to a significant $\mathrm{BrO}_{3}{ }^{-}$

214 formation. Therefore, increasing initial chlorine concentration shifts the bromine from organic 215 (e.g., THMs and HAAs) to inorganic (i.e., $\mathrm{BrO}_{3}{ }^{-}$) species (Figure S4, SI).

216 Increasing the initial chlorine concentrations from 14 to $40 \mu \mathrm{M}$ increased THM4 from $217194.9 \pm 6.5$ to $379.9 \pm 86.4 \mathrm{nM}$ (i.e., $47.6 \pm 1.6$ to $90.9 \pm 20.5 \mu \mathrm{g} \mathrm{L}{ }^{-1}$ ), but further increasing chlorine 
218 concentrations from 40 to $70 \mu \mathrm{M}$ led to a decreasing THM4. Bromoform was the main THM 219 species (>74.2\% among THM4), while $\mathrm{CHCl}_{3}, \mathrm{CHBrCl}_{2}$ and $\mathrm{CHBr}_{2} \mathrm{Cl}$ were the minor species. 220 In the presence of $\mathrm{CuO}$, the reaction between $\mathrm{HOBr}$ and $\mathrm{DOM}\left(\mathrm{CHBr}_{3}\right.$ formation $)$ competes with $221 \mathrm{HOBr}$ disproportionation $\left(\mathrm{BrO}_{3}{ }^{-}\right.$formtion). As above mentioned, in the second stage of reaction 222 (slow consumption kinetics), rate constant for $\mathrm{HOBr}$ disproportionation in the presence of $\mathrm{CuO}$ 223 is higher than $\mathrm{HOBr}$ reaction with slow reacting/unreactive DOM moieties, leading to the 224 preferential formation of $\mathrm{BrO}_{3}^{-}$. As a consequence, a decreasing $\mathrm{CHBr}_{3}$ formation was observed, 225 leading to a decreasing trend of THM4 since $\mathrm{CHBr}_{3}$ is the main species of THM4.

226 Lower concentrations of HAAs $\left(<43.6 \pm 3.1 \mathrm{nM}\right.$, i.e., $\left.8.6 \pm 0.6 \mu \mathrm{g} \mathrm{L}{ }^{-1}\right)$ were produced than 227 THMs. However, a similar trend of HAA formation vs. initial chlorine concentration was 228 observed. Total HAA concentrations increased with increasing initial chlorine concentrations 229 from 14 to $40 \mu \mathrm{M}$, but then decreased for high doses. This can be ascribed to the decreasing 230 formation of DBAA which was the main $\mathrm{HAA}$ species due to elevated $\mathrm{BrO}_{3}{ }^{-}$formation at initial 231 chlorine concentrations of 40 to $70 \mu \mathrm{M}$. However, meanwhile, the formation of other minor 232 chlorinated HAA species increased because high concentrations of chlorine facilitate the 233 oxidation of DOM moieties/intermediates. residual oxidant and DBP formation was investigated (Figures S5, SI). Significant oxidant 237 consumption (i.e., 39.3\%-80\%) was observed, which increased with increasing initial $\mathrm{Br}^{-}$ 238 concentration from 0.5 to $10 \mu \mathrm{M}$ (i.e., $40-800 \mu \mathrm{g} \mathrm{L}^{-1}$ ), since $\mathrm{HOBr}$ reacts with DOM and $\mathrm{CuO}$ 239 faster than $\mathrm{HOCl}$ at $\mathrm{pH} 8.6 .^{6,19}$ Bromate was only observed at high $\mathrm{Br}^{-}$concentration $(\geq 5 \mu \mathrm{M})$, 
240 because at low $\mathrm{Br}^{-}$concentration $(<5 \mu \mathrm{M})$, the formed $\mathrm{HOBr}$ was mainly consumed by the 241 reactive DOM moieties.

242 An elevated THM formation was observed for an increasing initial $\mathrm{Br}^{-}$concentration (Figure $243 \mathrm{~S} 5 \mathrm{~b}, \mathrm{SI})$, which is similar to previous studies performed in the absence of $\mathrm{CuO} .{ }^{10,31}$ In the 244 absence of $\mathrm{Br}^{-}$, only $\mathrm{CHCl}_{3}(106.4 \pm 2.4 \mathrm{nM})$ was formed from the chlorination of DOM. 245 Increasing the $\mathrm{Br}^{-}$concentration led to less $\mathrm{CHCl}_{3}$ formation, but enhanced the formation of 246 brominated THMs. At an initial $\mathrm{Br}^{-}$concentration of $2 \mu \mathrm{M}$, chlorine concentration $\left([\mathrm{HOCl}]_{0}=40\right.$ $247 \mu \mathrm{M}$ ) was 10 times higher than bromine. However, the formed $\mathrm{CHCl}_{3}$ was less than that of $248 \mathrm{CHBr}_{3}(36.8 \mathrm{nM}$ vs $57.2 \mathrm{nM})$, indicating that the ability of bromine to produce THMs is at least 24910 times higher than chlorine in the presence of $\mathrm{CuO}$.

250 The formation of HAAs was significantly less than THMs. DCAA, TCAA, BCAA and 251 DBAA were detected (Figure S5c, SI). In a manner analogous to that observed for THMs, 252 increasing the initial $\mathrm{Br}^{-}$concentration shifts the speciation of HAAs from chlorinated to 253 brominated species, which is similar to previous studies conducted in the absence of $\mathrm{CuO} .^{10,32,33}$ 254 Increasing the initial $\mathrm{Br}^{-}$concentration leads to enhanced $\mathrm{BrO}_{3}^{-}$formation and bromine 255 incorporated in THMs and HAAs. However, this reduces the incorporation of chlorine atom 256 (Figure S6, SI), since chlorine is consumed by the increasing $\mathrm{Br}^{-}$in the solution, thus decreasing 257 available chlorine that can react with DOM. Increasing the initial $\mathrm{Br}^{-}$concentration significantly 258 enhances the formation of THM4, but no significant enhancement of total HAA formation was 259 observed, leading to an increasing ratio of total THMs/HAAs with the increasing initial $\mathrm{Br}^{-}$ 260 concentration. This indicates that $\mathrm{Br}^{-}$favours the formation of THMs in the presence of $\mathrm{CuO}$, 261 comparing with HAAs, probably because more THM precursors are available than HAA 
262 precursors in the studied DOM. It was reported that THM and HAA can be formed from 263 different precursors. ${ }^{30}$

264

265

266

267

268

269

270

271

272

273

274

275

276

277

278

279

280

281

282

283

Effect of pH. During the chlorination of bromide-containing waters in the presence of $0.025 \mathrm{~g} \mathrm{~L}^{-1} \mathrm{CuO}$ and DOM, significant oxidant decay $(\geq 75.5 \%)$ was observed at a reaction time of $8 \mathrm{~h}$ within the range of $\mathrm{pH}$ 6.6-9.6 (Figure 3). The corresponding $\mathrm{BrO}_{3}{ }^{-}$concentrations were 7.0 $\pm 3.0,13.2 \pm 0.4,33.6 \pm 2.1$ and $2.8 \mu \mathrm{g} \mathrm{L}^{-1}$ for $\mathrm{pH}$ 6.6, 7.6, 8.6, and 9.6, respectively. Maximum $\mathrm{BrO}_{3}{ }^{-}$formation was at $\mathrm{pH} 8.6$ near its $p \mathrm{~K}_{\mathrm{a}}$ (i.e., 8.8), since the CuO-catalyzed disproportionation of $\mathrm{HOBr}$ occurs via the interaction between $\mathrm{HOBr}$ and $\mathrm{OBr}^{-19,24}$

The concentration of $\mathrm{BrO}_{3}{ }^{-}$was lower than that of total bromine in THMs and HAAs, which increased with increasing $\mathrm{pH}$ (Figure S7, SI). Significant amounts of THMs were formed within the range of $\mathrm{pH}$ 6.6-9.6, e.g., THM4 were $169.4 \pm 12.6,283.7 \pm 64.7,379.9 \pm 86.4$ and $473.4 \pm 118.2$ $\mathrm{nM}$ (i.e., 39.2 $\pm 2.5,65.8 \pm 15.0,90.9 \pm 20.4$ and $108.9 \pm 24.0 \mu \mathrm{g} \mathrm{L}^{-1}$ ) for $\mathrm{pH} 6.6,7.6,8.6$ and 9.6, respectively. The upward trend in THM formation with $\mathrm{pH}$ was also reported in previous studies performed in the absence of $\mathrm{CuO}^{34,35}$ Hypohalous acid $(\mathrm{HOCl} / \mathrm{HOBr})$ that is present as nondissociating species at lower $\mathrm{pH}(\mathrm{e} . \mathrm{g} ., \mathrm{3} .6)$ shows a higher reactivity than its hypohalite ion towards DOM. ${ }^{11,36}$ However, THM formation is a multi-step process. The enolization of carbonyl moiety of DOM or the hydrolysis of intermediate (e.g., trihalocarbonyl) to THM could be the rate-limiting step and both pathways can be catalyzed by hydroxide ion. ${ }^{37}$ It is likely that these reactions play much more important roles in determining the $\mathrm{pH}$ effect on the THM formation. Again, less HAAs $\left(\leq 43.6 \pm 3.1 \mathrm{nM}\right.$, i.e., $\left.8.6 \pm 0.6 \mu \mathrm{g} \mathrm{\textrm {L } ^ { - 1 }}\right)$ were formed than THMs within the range of $\mathrm{pH}$ 6.6-9.6. HAA formation increased as the $\mathrm{pH}$ increased from 6.6 to 8.6 and 
284 then slightly decrease within $\mathrm{pH}$ range of 8.6-9.6. DBAA were the main HAA species, while 285 DCAA, TCAA and BCAA were minor species.

286

287

288

289

290

291

292

293

294

295

296

297

298

299

300

301

302

303

304

305

306

Effect of the initial DOM concentration.

Figure S8 (SI) shows the influence of initial DOM concentration (1.25-20 $\left.\mathrm{mg} \mathrm{L}^{-1}\right)$ on the oxidant demand and DBP formation. In the absence of DOM, the residual oxidant and $\mathrm{BrO}_{3}{ }^{-}$at a reaction time of $8 \mathrm{~h}$ were $7.0 \pm 0.1$ and $7.5 \pm 0.1 \mu \mathrm{M}$, respectively (Figure S9, SI). Increasing the initial DOM concentration decreases the residual oxidant concentration and $\mathrm{BrO}_{3}{ }^{-}$formation due to the reaction between bromine and DOM. The presence of $1.25 \mathrm{mg} \mathrm{L}^{-1} \mathrm{DOM}$ significantly reduced $\mathrm{BrO}_{3}{ }^{-}$concentrations from $957.7 \pm 13$ to $58.3 \pm 11.7 \mu \mathrm{g} \mathrm{L}^{-1}$. When DOM concentration is higher than $5 \mathrm{mg} \mathrm{L}^{-1}, \mathrm{BrO}_{3}{ }^{-}$concentration is $<5$ $\mu \mathrm{g} \mathrm{L}^{-1}$, indicating that the $\mathrm{HOBr}$ reaction with $\mathrm{DOM}$ will predominate in the presence of higher concentrations of DOM.

Increasing initial DOM concentrations $\left(0-20 \mathrm{mg} \mathrm{L}^{-1}\right)$ shifts bromine speciation from $\mathrm{BrO}_{3}{ }^{-}$to organic brominated byproducts (e.g., THMs and HAAs) (Figure S10, SI). THM4 (64.0 \pm 15.5 138.9 $\pm 2.1 \mu \mathrm{g} \mathrm{L}^{-1}$ ) increased with increasing DOM concentrations from 1.25 to $20 \mathrm{mg} \mathrm{L}^{-1}$. Again, $\mathrm{CHBr}_{3}$ was the main THM species, whereas $\mathrm{CHCl}_{3}, \mathrm{CHBrCl}_{2}$ and $\mathrm{CHBr}_{2} \mathrm{Cl}$ were the minor species.

Increasing the DOM concentration only slightly increased the HAAs formation from $48.0 \pm 2.1$ to $63.9 \pm 1.5 \mathrm{nM}$ (i.e., $8.1 \pm 0.4$ to $11.2 \pm 0.3 \mu \mathrm{g} \mathrm{\textrm {L } ^ { - 1 }}$ ) (Figure S8c, SI). DCAA, TCAA, BCAA and DBAA were detected. At lower initial DOM concentration $\left(1.25-2.5 \mathrm{mg} \mathrm{L}^{-1}\right)$, the heterogeneous $\mathrm{HOBr}$ involved reactions on the $\mathrm{CuO}$ surface predominate, since $\mathrm{HOBr}$ is much more readily activated by $\mathrm{CuO}$ than $\mathrm{HOCl}$. Increasing the initial DOM concentration increased the DBAA formation. At higher DOM concentration $\left(>2.5 \mathrm{mg} \mathrm{L}^{-1}\right)$, the direct homogeneous 
reactions between $\mathrm{HOCl}$ and fast reacting DOM moiety becomes significant, leading to the enhanced formation of chlorinated HAAs. Elevated BCAA formation even led to a slight decreasing DBAA formation with the increasing DOM concentration from 2.5 to $20 \mathrm{mg} \mathrm{L}^{-1}$.

\section{Effect of the type of DOM. Oxidant decay and DBP formation in the presence of six} types of DOM isolates were studied (Figure 4, Figures S11-13, SI). The six DOM isolates exhibited a wide range of SUVA $_{254}$ values (Table S1, SI). SRW-HPOA showed the highest SUVA $_{254}\left(4.9 \mathrm{~L} \mathrm{mg}^{-1} \mathrm{~m}^{-1}\right.$ ), indicating a high aromatic character (i.e., high reactivity toward oxidants), followed by LRW-HPO, RRW-HPO and CRW-PI1-HPO, with SUVA 254 values of 3.5, 3.1 and 2.0 $\mathrm{L} \mathrm{mg}^{-1} \mathrm{~m}^{-1}$, respectively. CRW-F2E-HPO and CRW-BF-HPO are extracted from treated Colorado River water (CRW-PI1-HPO), showing lower SUVA 254 values of 1.7 and $1.1 \mathrm{~L}$ $\mathrm{mg}^{-1} \mathrm{~m}^{-1}$, respectively.

After $2 \mathrm{~h}$ chlorination of these DOM isolates in the presence of $\mathrm{Br}^{-}$, residual oxidant varied from 20.5 to $30.0 \mu \mathrm{M}$ (Figure S11, SI). Increasing the aromaticity of DOM (i.e., SUVA 254 ) led to decreased residual oxidant but enhanced formation of total THMs and HAAs (Figure 4). For example, CRW-BF-HPO isolated after advanced treatment of raw water for CRW-PI1-HPO is the lowest reactive fraction, producing lowest total THMs and HAAs. SRW-HPOA, humic substances with the highest $\mathrm{SUVA}_{254}$ value among the six DOM isolates form $161.6 \pm 8.6$ and $26.2 \pm 1.2 \mu \mathrm{g} \mathrm{L}^{-1}$ for total THMs and HAAs, respectively. This trend agrees well with the percentage of humic substances in DOM characterized in Figure S14 (SI). Humic substances with the high aromatic/phenolic carbon and carboxyl group contents are the fast reacting THM/HAA precursors. ${ }^{29}$ 
In the presence of $\mathrm{CuO}$, less oxidant $(7.9-10.3 \mu \mathrm{M})$ remained due to the interaction between

$330 \mathrm{CuO}$ and $\mathrm{HOCl} / \mathrm{HOBr} .{ }^{19}$ Bromate formation was only detected in the presence of two DOM

331 fractions isolated from treated waters $\left(29.1 \pm 2.4\right.$ and $2.8 \mu \mathrm{g} \mathrm{L}^{-1}$ for CRW-BF-HPO and CRW-

332 F2E-HPO, respectively) (Figure S12, SI). In the presence of DOM isolates collected from raw

333 waters with higher $\mathrm{SUVA}_{254}$ values, the formed $\mathrm{HOBr}$ was mainly consumed by its reaction with

334 fast reacting DOM moieties (e.g., humic substances) and disproportionation is insignificant.

335 The presence of $\mathrm{CuO}$ generally enhanced the formation of total THMs and HAAs and 336 bromine/chlorine atom in THMs and HAAs (except from SRW-HPOA). DOM with the highest

337 SUVA $_{254}$ value (e.g., SRW-HPOA) exhibited the lowest enhancement (Figures 4 and S15, SI).

338 For example, an increase of $124 \%$ for the THM4 formed from CRW-BF-HPO by CuO was 339 observed, while this was only $21.8 \%$ for SRW-HPOA. For HAA formation, there is even no 340 enhancement for SRW-HPOA. This may indicate that $\mathrm{CuO}$ can enhance the reactions with 341 relatively low rate constants.

342 The speciation of THMs and HAAs in the presence of $\mathrm{CuO}$ was similar to that in the absence 343 of $\mathrm{CuO}$. Among the formed THMs and HAAs, $\mathrm{CHBr}_{3}$ and $\mathrm{DBAA}$ were the main species, 344 respectively. In contrast, $\mathrm{CHCl}_{3}, \mathrm{CHBrCl}_{2}$ and $\mathrm{CHBr}_{2} \mathrm{Cl}$ were minor $\mathrm{THM}$ species, and DCAA, 345 TCAA, BCAA and BDCAA were formed at lower concentrations than DBAA (Figures S13, SI).

Formation of bromate, THMs and HAAs from bromination of model compounds. Because the structure of DOM moieties is ambiguous and variable, the investigation of model compounds provides information on the kinetics and mechanisms responsible for DBP formation. Table 1 summarizes the consumption of $\mathrm{HOBr}$, formation of $\mathrm{BrO}_{3}{ }^{-}, \mathrm{CHBr}_{3}$ and 
351 DBAA from $\mathrm{HOBr}$ reactions with various model compounds and their reaction rate constants 352 with bromine are shown in Table S3 (SI).

353 Second-order rate constants $(\mathrm{k})$ for bromine reactions with acetone, n-butanol, propionic and 354 butyric acids are $<1 \mathrm{M}^{-1} \mathrm{~s}^{-1}$, which are considered as practically unreactive compounds. ${ }^{11}$ Slight 355 HOBr consumption $(\leq 4.6 \%)$ was observed and $\mathrm{CHBr}_{3}$ was the only DBP formed at $2 \mathrm{~h}$ (Table 356 1). Among them, acetone shows the highest $\mathrm{CHBr}_{3}$ formation via the classical haloform 357 formation pathway. ${ }^{11}$ Similar $\mathrm{HOBr}$ consumption and $\mathrm{BrO}_{3}{ }^{-}$formation comparing with that in 358 the absence of model compounds indicates that the presence of practically unreactive compounds 359 does not affect the disproportionation of $\mathrm{HOBr}$. However, the presence of $\mathrm{CuO}$ changes the $360 \mathrm{CHBr}_{3}$ and DBAA formation. The $\mathrm{CHBr}_{3}$ formation from propionic and butyric acids was 361 slightly enhanced, while its formation from acetone and n-butanol was inhibited by $\mathrm{CuO}$. The 362 reason is unknown, but it is likely that the structure of model compounds will also determine the 363 extent for the enhancement of $\mathrm{CHBr}_{3}$ formation by $\mathrm{CuO}$. Interestingly, DBAA were additionally 364 formed, indicating that $\mathrm{CuO}$ can enhance the reactivity of $\mathrm{HOBr}$ via the electron transfer 365 pathway to oxidize acetone and n-butanol to their acid forms.

366 Oxalic, malonic, succinic and citric acids are considered as slow reacting compounds which 367 react with bromine with second-order rate constants $>1 \mathrm{M}^{-1} \mathrm{~s}^{-1}\left(k=40\right.$ and $30 \mathrm{M}^{-1} \mathrm{~s}^{-1}$ for oxalic 368 and malonic acids, respectively ${ }^{38}$ ). At $2 \mathrm{~h},<6.8 \%$ of $\mathrm{HOBr}$ was consumed (Table 1). Citric acid 369 is the strongest precursor of THM and HAA $(375.7 \pm 36.7 \mathrm{nM}$ and $31.6 \pm 6.8 \mathrm{nM}$, respectively). It 370 was known as an important $\mathrm{CHCl}_{3}$ precursor during the analogous chlorination process through 371 multi-steps (e.g., oxidative decarboxylation, halogenation of methylene groups and subsequent 372 hydrolysis of intermediates). ${ }^{39-41}$ The formation of THM and HAA (i.e., $\leq 4.2 \pm 0.3$ and $\leq 2.2 \pm 0.1$ 
$373 \mathrm{nM}$, respectively) from oxalic, malonic, and succinic acids was lower, which agrees with 374 previous studies. ${ }^{42,43}$

375 The presence of $\mathrm{CuO}$ significantly enhanced the consumption of $\mathrm{HOBr}$ in the presence of 376 these slow reacting compounds $(\geq 93.2 \%)$. Bromate was not detected in the presence of oxalic 377 and malonic acids but its concentrations in the presence of succinic and citric acids were $1.5 \pm 0.1$ 378 and $0.2 \mu \mathrm{M}$, respectively. CuO-catalyzed disproportionation of $\mathrm{HOBr}$ is in competition with the 379 heterogeneous reactions between $\mathrm{CuO}-\mathrm{HOBr}$ and slow reacting compounds. Therefore, the 380 contribution for the latter pathway follows the sequence of oxalic $\cong$ malonic $>$ citric $>$ succinic 381 acids. The enhanced formation of $\mathrm{CHBr}_{3}$ and DBAA comparing with homogenous solutions 382 indicates that the bromination pathway is enhanced by $\mathrm{CuO}$. Citric acid showed the highest $383 \mathrm{CHBr}_{3}$ and DBAA formation among slow reacting compounds. The rate-limiting step (i.e., 384 decarboxylation of citric acid to 3-oxopentanedioic acid) seems to be significantly enhanced by $385 \mathrm{CuO}$. Both brominated DBPs and $\mathrm{BrO}_{3}{ }^{-}$formation are insignificant in the presence of oxalic acid, 386 implying an oxidation of oxalic acid to carbon dioxide.

387 Rate constants for the reactions between $\mathrm{HOBr}$ and phenolic compounds are $>10^{4} \mathrm{M}^{-1} \mathrm{~s}^{-1}$, 388 and thus they are included as fast reacting compounds, ${ }^{44-48}$ consuming $>84 \%$ of $\mathrm{HOBr}$ after $2 \mathrm{~h}$. 389 Resorcinol known as a fast $\mathrm{CHCl}_{3}$ precursor, ${ }^{49-51}$ shows the highest $\mathrm{CHBr}_{3}$ formation $390(6367.5 \pm 35.0 \mathrm{nM})$. In contrast, $\mathrm{CHBr}_{3}$ formation from other phenolic compounds is significantly 391 lower $(<49.1 \pm 2.3 \mathrm{nM})$. Phenol was known as a slow $\mathrm{CHCl}_{3}$ precursor and the bromination of 392 hydroquinone and catechol occurs predominately via the oxidation pathway. ${ }^{48-51}$ Phenolic 393 compounds do not form significant amount of DBAA $(<7.1 \pm 0.9 \mathrm{nM})$. Because $\mathrm{HOBr}$ reacts 394 quickly with phenolic compounds, heterogeneous reactions on the $\mathrm{CuO}$ surface tends to be less 
395 significant, leading to the insignificant enhanced formation of $\mathrm{BrO}_{3}{ }^{-}, \mathrm{CHBr}_{3}$ and DBAA. (Table 396 1).

397 Based on our results, it can be concluded that the $\mathrm{BrO}_{3}{ }^{-}$formation decreases as the reactivity 398 of models compounds with bromine increases. $\mathrm{CuO}$ can activate the reactivity of $\mathrm{HOBr}$ towards 399 slow reacting compounds (e.g., di- and tri-carboxylic acids), leading to elevated $\mathrm{CHBr}_{3}$ and 400 DBAA formation. However, no significant effect was observed for practically unreactive or fast 401 reacting phenolic compounds. These results confirm again the significant enhancement for slow 402 reacting DOM isolates (e.g., CRW-BF-HPO, mainly comprising fulvic acid structures 403 incorporating abundant polysaccharides moieties ${ }^{29}$ ). However, DOM isolates such as SRW404 HPOA (predominance of high aromatic/phenolic carbon and carboxyl group contents ${ }^{29}$ ) exhibit 405 less enhancement. containing waters in the presence of DOM. Scheme 1 shows a hypothetical formation 409 mechanism of $\mathrm{BrO}_{3}{ }^{-}$and halogenated DBPs during chlorination of bromide-containing waters in 410 the presence of $\mathrm{DOM}$ and $\mathrm{CuO}$. The reaction is initiated by the rapid oxidation of $\mathrm{Br}^{-}$by $\mathrm{HOCl}$ to $411 \mathrm{HOBr} / \mathrm{OBr}^{-}$(reaction 1). ${ }^{8}$ The formed $\mathrm{HOBr} / \mathrm{OBr}^{-}$can compete with $\mathrm{HOCl} / \mathrm{OCl}^{-}$to react with 412 fast reacting DOM moieties (e.g., phenolic) via electrophilic substitutions (reaction 2a) and 413 oxidation (reaction $2 \mathrm{~b})\left(\mathrm{k}=500-5000 \mathrm{M}^{-1} \mathrm{~s}^{-1}\right){ }^{6,11}$ Reaction $2 \mathrm{a}$ forms brominated DBPs, while 414 reaction $2 \mathrm{~b}$ produces oxidized $\mathrm{DOM}\left(\mathrm{DOM}_{\mathrm{ox}}\right)$ with the release of $\mathrm{Br}^{-}$, which can be re-oxidized 415 to $\mathrm{HOBr}$ in excess of $\mathrm{HOCl}$ (catalytic cycle). The latter one is the main pathway for bromination 416 of most DOM. ${ }^{52}$ 
In the presence of $\mathrm{CuO}, \mathrm{HOBr}$ can combine with $\mathrm{CuO}$ to form a $\mathrm{CuO}-\mathrm{HOBr}$ complex

418 (reaction 3). Complexation of $\mathrm{HOBr} \mathrm{OBr}^{-}$by the Lewis acid $\mathrm{CuO}$ polarizes the bromine

419 molecule, thus increasing its electrophilicity and as a consequence its reactivity. The $\mathrm{CuO}-\mathrm{HOBr}$

420 complex reacts with $\mathrm{HOBr}$ to generate oxygen and $\mathrm{Br}^{-}$(reaction 4) or form $\mathrm{BrO}_{3}^{-}$(i.e.,

421 disproportionation pathway, reaction 5). ${ }^{19}$ Moreover, this complex can react with slow reacting

422 DOM moieties, leading to the formation of brominated DBPs (reaction 6a) or DOM ox $_{(\text {reaction }}$

423 6b). Estimated second-order rate constants for reactions 4 and 5 range between 1 and $500 \mathrm{M}^{-1} \mathrm{~s}^{-1}$

424 according to previous kinetical model. ${ }^{19}$ Therefore, upon the complete degradation of fast

425 reacting DOM moieties, in order to form both halogenated DBPs and $\mathrm{BrO}_{3}{ }^{-}$the rate constant for

$426 \mathrm{CuO}-\mathrm{HOBr}$ complex reaction with slow reacting DOM moieties (e.g., alcohol, ketone,

427 carboxylic, etc) should be in the same order of magnitude with reaction $5\left(\mathrm{k}=1-500 \mathrm{M}^{-1} \mathrm{~s}^{-1}\right)$.

428 Meanwhile, since the reaction between $\mathrm{HOBr}$ and slow reacting DOM is enhanced by $\mathrm{CuO}$,

429 elevated brominated DBPs can be formed.

$430 \mathrm{HOCl}$ will also react with fast reacting DOM moieties to produce chlorinated DBPs or $431 \mathrm{DOM}_{\mathrm{ox}}$ (reactions $12 \mathrm{a}$ and 12b, respectively), approximately 10 times slower than the 432 corresponding bromine reaction. ${ }^{6}$ Similarly, $\mathrm{HOCl}$ can combine with $\mathrm{CuO}$ to form a $\mathrm{CuO}-\mathrm{HOCl}$ 433 complex (reaction 13), which reacts with itself to produce oxygen and chlorate $\left(\mathrm{ClO}_{3}{ }^{-}\right)($reactions

43414 and 15 , respectively). ${ }^{19}$ Reaction 14 is the major pathway, while reaction 15 is a minor 435 pathway. Therefore, even $\mathrm{ClO}_{3}{ }^{-}$can be formed in $\mathrm{CuO}-\mathrm{HOCl}$ system, in the presence of DOM 436 and $\mathrm{Br}^{-}$, the formation of $\mathrm{ClO}_{3}{ }^{-}$is insignificant since the rate constants for reactions 1,12 , and 43714 are higher than reaction 15 ( $\mathrm{HOCl}$ disproportionation). Because of the chemical similarity of $438 \mathrm{HOCl}$ with $\mathrm{HOBr}$, it is expected that $\mathrm{CuO}$ can enhance the reactivity of $\mathrm{HOCl}$ towards the slow 439 reacting DOM moieties, leading to elevated chlorinated DBPs or $\mathrm{DOM}_{\mathrm{ox}}$ (reactions $16 \mathrm{a}$ and $16 \mathrm{~b}$, 
440 respectively). However, rate constant for reaction 16 may be smaller than that of reaction 6 (i.e., 441 bromination of DOM in the presence of $\mathrm{CuO}$ ).

Implications on water treatment. Our results highlight that in the presence of DOM 443 isolated from treated water that are representative of distributed drinking water, both $\mathrm{BrO}_{3}{ }^{-}$and 444 brominated DBP formation can be enhanced in the presence of $\mathrm{CuO}$. $\mathrm{CuO}$ is present on the 445 surface of copper pipes owning to the pipe corrosion. ${ }^{21,23}$ This would raise a serious drinking 446 water safety issue in distribution systems and household plumbing.

Bromide levels in raw waters are highly variable in a range from $<10$ to $>1000 \mu \mathrm{g} \mathrm{\textrm {L } ^ { - 1 } . 5 3} \mathrm{A}$ survey over 23 water supplies in the USA and Canada showed that $\mathrm{Br}^{-}$levels ranged from 24 to $1120 \mu \mathrm{g} \mathrm{L}^{-1}$ (median of $109 \mu \mathrm{g} \mathrm{L}^{-1}$ ) in source waters. ${ }^{54}$ Based on our results, it can be expected 450 that $\mathrm{BrO}_{3}{ }^{-}$formation should not be of concern when $\mathrm{Br}^{-}$is present at concentration around 100

$451 \mu \mathrm{g} \mathrm{L}^{-1}$ (median level in natural waters in USA). However, when potable water is produced from 452 desalinated seawater, ${ }^{5,56}$ groundwater $^{57}$ with high $\mathrm{Br}^{-}$content (i.e., $>400 \mu \mathrm{g} \mathrm{L}^{-1}$ ) and low DOC, 453 the risk of producing $\mathrm{BrO}_{3}{ }^{-}$exists. This may also apply to treated surface water in seasonal 454 seawater intrusion in coastal cities and some regions with $\mathrm{Br}^{-}$enriched water (e.g., Australia, ${ }^{57}$ ), 455 considering that $\mathrm{Br}^{-}$is not removed in conventional treatment train while a large fraction of the 456 DOM incorporating the fast reacting moieties is generally eliminated. For treated water with high 457 concentrations of both $\mathrm{Br}^{-}$and DOM moieties (e.g., blending desalinated seawater with other 458 source water), the possibility to produce $\mathrm{BrO}_{3}{ }^{-}$is reduced. However, elevated THMs and HAAs 459 can be expected, since $\mathrm{CuO}$ can activate the reactivity of $\mathrm{HOBr}$ towards hydrophilic carboxylic 460 acids leading to enhanced DBP formation from DOM moieties that are not originally expected to 461 form significant DBPs during disinfection. Accordingly, this will be a challenge to meet the 
462 MCL for THM4 in drinking water (e.g., $80 \mu \mathrm{g} \mathrm{L}^{-1}$ by US EPA, Figures 2-3, and Figures S5 and 463 S8, SI).

464 It should be noted that our data were obtained in a batch reactor which provides a different 465 hydraulic and operational condition from distribution systems. Therefore, additional studies will 466 be required in a long-term running copper-containing pilot-scale/full-scale distribution system to 467 assess the kinetics of oxidant decay and the formation of $\mathrm{BrO}_{3}{ }^{-}$, THMs, HAAs and emerging 468 DBPs (e.g., haloacetonitriles and haloketones)

- Supporting Information

471 Additional details of chemicals, methods, tables and figures. This material is available free of 472 charge via the Internet at http://pubs.acs.org.

473 - Acknowledgements

474 The authors would like to thank Julien Le Roux for the help on THM and HAA analyses. The 475 authors acknowledge the funding and support from KAUST. 


\section{- References}

(1) Deborde, M.; von Gunten, U., Reactions of chlorine with inorganic and organic compounds during water treatment-Kinetics and mechanisms: A critical review. Water Res. 2008, 42, 13-51.

(2) Sedlak, D. L.; von Gunten, U., The Chlorine Dilemma. Science 2011, 331, (6013), 42-43.

(3) Richardson, S. D.; Plewa, M. J.; Wagner, E. D.; Schoeny, R.; DeMarini, D. M., Occurrence, genotoxicity, and carcinogenicity of regulated and emerging disinfection by-products in drinking water: A review and roadmap for research. Mutat Res-rev Mutat 2007, 636, (1-3), 178-242.

(4) Rook, J. J., Formation of haloforms during chlorination of natural waters. Water Treatment \& Examination 1974, 23, 234-243.

(5) Gallard, H.; von Gunten, U., Chlorination of natural organic matter: kinetics of chlorination and of THM formation. Water Res 2002, 36, (1), 65-74.

(6) Westerhoff, P.; Chao, P.; Mash, H., Reactivity of natural organic matter with aqueous chlorine and bromine. Water Res 2004, 38, (6), 1502-1513.

(7) Reckhow, D. A.; Singer, P. C.; Malcolm, R. L., Chlorination of humic materials: byproduct formation and chemical interpretations. Environ Sci Technol 1990, 24, (11), 1655-1664.

(8) Kumar, K.; Margerum, D. W., Kinetics and mechanism of general- acid-assisted oxidation of bromide by hypochlorite and hypochlorous acid. Inorg Chem 1987, 26, (16), 2706-2711.

(9) Krasner, S. W.; Weinberg, H. S.; Richardson, S. D.; Pastor, S. J.; Chinn, R.; Sclimenti, M. J.; Onstad, G. D.; Thruston, A. D., Jr., Occurrence of a new generation of disinfection byproducts. Environ Sci Technol 2006, 40, (23), 7175-7185.

(10) Hua, G.; Reckhow, D. A.; Kim, J., Effect of bromide and iodide ions on the formation and speciation of disinfection by-products during chlorination. Environ Sci Technol 2006, 40, 3050-3056.

(11) Heeb, M. B.; Criquet, J.; Zimmermann-Steffens, S. G.; von Gunten, U., Bromine production during oxidative water treatment of bromide-containing waters and its reactions with inorganic and organic compounds: A critical review. Water Res 2014, 48, (1), 15-42.

(12) U.S. Environmental Protection Agency, National Primary Drinking Water Regulations. In Washington D.C., 2001.

(13) European Communities, European Communities (Drinking water) (No.2) Regulations. In Brussels, 2007.

(14) Ministry of Public Health of China, Standard for Drinking Water Quality. Beijing, China. 2006.

(15) von Gunten, U., Ozonation of drinking water: Part II. Disinfection and by-product formation in presence of bromide, iodide or chlorine. Water Res 2003, 37, (7), 1469-1487.

(16) von Gunten, U.; Hoigné, J., Bromate formation during ozonation of bromide-containing waters: Interaction of ozone and hydroxyl radical reactions. Environ Sci Technol 1994, 28, 1234-1242.

(17) Haag, W. R.; Hoigné, J., Ozonation of bromide-containing waters: kinetics of formation of hypobromous acid and bromate. Environ Sci Technol 1983, 17, 261-267.

(18) Margerum, D. W.; Huff Hartz, K. E., Role of halogen(I) cation-transfer mechanisms in water chlorination in the presence of bromide ion. J. Environ. Monit. 2002, 4, 20-26.

(19) Liu, C.; von Gunten, U.; Croué, J.-P., Enhanced bromate formation during chlorination of bromide-containing waters in the presence of $\mathrm{CuO}$ : Catalytic disproportionation of hypobromous acid. Environ Sci Technol 2012, 46, (20), 11054-11061.

(20) Feng, Y.; Teo, W. K.; Siow, K. S.; Tan, K. 1.; Hsieh, A. K., The corrosion behaviour of copper in neutral tap water. Part I: Corrosion mechanisms. Corros Sci 1996, 38, (3), 369-385.

(21) Shim, J. J.; Kim, J. G., Copper corrosion in potable water distribution systems: influence of copper products on the corrosion behavior. Mater Lett 2004, 58, 2002-2006.

(22) Li, B.; Liu, R. P.; Liu, H. J.; Gu, J. N.; Qu, J. H., The formation and distribution of haloacetic acids 9 in copper pipe during chlorination. J Hazard Mater 2008, 152, (1), 250-258. 
(23) Li, B.; Qu, J.; Liu, H.; Hu, C., Effects of copper(II) and copper oxides on THMs formation in copper pipe. Chemosphere 2007, 68, 2153-2160.

(24) Liu, C.; von Gunten, U.; Croué, J.-P., Chlorination of bromide-containing waters: Enhanced bromate formation in the presence of synthetic metal oxides and deposits formed in drinking water distribution systems. Water Res 2013, 47, (14), 5307-5315.

(25) Liu, C.; von Gunten, U.; Croué, J.-P., Enhanced chlorine dioxide decay in the presence of metal oxides: Relevance to drinking water distribution systems. Environ Sci Technol 2013, 47, (15), 8365-8372.

(26) Liu, C.; Salhi, E.; Croué, J.-P.; von Gunten, U., Chlorination of iodide-containing waters in the presence of CuO: Formation of periodate. Environ Sci Technol 2014, 48, (22), 13173-13180.

(27) Zhang, H.; Andrews, S. A., Catalysis of copper corrosion products on chlorine decay and HAA formation in simulated distribution systems. Water Res 2012, 46, (8), 2665-2673.

(28) Stumm, W., Chemistry of the Solid-Water Interface, JohnWiley and Sons, New York. 1992.

(29) Hwang, C. J.; Krasner, S. W.; Sclimenti, M. J.; Amy, G. L.; Dickenson, E.; Bruchet, A.; Prompsy, C.; Filippi, G.; Croué, J.-P.; Violleau, D., Polar NOM: Characterization, DBPs, and Treatment. Denver, Colorado: American Water Works Association Research Foundation and American Water Works Association. 2001.

(30) Hua, G.; Reckhow, D. A., Characterization of Disinfection Byproduct Precursors Based on Hydrophobicity and Molecular Size. Environ Sci Technol 2007, 41, (9), 3309-3315.

(31) Hu, J.; Song, H.; Karanfil, T., Comparative Analysis of Halonitromethane and Trihalomethane Formation and Speciation in Drinking Water: The Effects of Disinfectants, $\mathrm{pH}$, Bromide, and Nitrite. Environ Sci Technol 2010, 44, (2), 794-799.

(32) Wu, W.; Chadik, P., Effect of Bromide Ion on Haloacetic Acid Formation during Chlorination of Biscayne Aquifer Water. J Environ Eng 1998, 124, (10), 932-938.

(33) Cowman, G. A.; Singer, P. C., Effect of Bromide Ion on Haloacetic Acid Speciation Resulting from Chlorination and Chloramination of Aquatic Humic Substances. Environ Sci Technol 1995, 30, (1), 16-24.

(34) Luong, T. V.; Peters, C. J.; Perry, R., Influence of bromide and ammonia upon the formation of trihalomethanes under water-treatment conditions. Environ Sci Technol 1982, 16, (8), 473-479.

(35) Hua, G.; Reckhow, D. A., Evaluation of bromine substitution factors of DBPs during chlorination and chloramination. Water Res 2012, 46, (13), 4208-4216.

(36) Deborde, M.; von Gunten, U., Reactions of chlorine with inorganic and organic compounds during water treatment - Kinetics and mechanisms: A critical review. Water Res 2008, 42, (1-2), 13-51.

(37) Bichsel, Y.; von Gunten, U., Formation of iodo-trihalomethanes during disinfection and oxidation of iodide containing waters. Environ Sci Technol 2000, 34, (13), 2784-2791.

(38) Pinkernell, U.; von Gunten, U., Bromate minimization during ozonation: Mechanistic considerations. Environ Sci Technol 2001, 35, (12), 2525-2531.

(39) Blatchley, E. R.; Margetas, D.; Duggirala, R., Copper catalysis in chloroform formation during water chlorination. Water Res 2003, 37, (18), 4385-4394.

(40) Larson, R. A.; Rockwell, A. L., Citric acid: Potential precursor of chloroform in water chlorination. Naturwissenschaften 1978, 65, (9), 490-490.

(41) Larson, R. A.; Rockwell, A. L., Chloroform and chlorophenol production by decarboxylation of natural acids during aqueous chlorination. Environ Sci Technol 1979, 13, (3), 325-329.

(42) Bond, T.; Henriet, O.; Goslan, E. H.; Parsons, S. A.; Jefferson, B., Disinfection Byproduct Formation and Fractionation Behavior of Natural Organic Matter Surrogates. Environ Sci Technol 2009, 43, (15), 5982-5989.

(43) Wang, Y.; Le Roux, J.; Zhang, T.; Croué, J.-P., Formation of Brominated Disinfection Byproducts from Natural Organic Matter Isolates and Model Compounds in a Sulfate RadicalBased Oxidation Process. Environ Sci Technol 2014, 48, (24), 14534-14542. 
(44) Acero, J. L.; Piriou, P.; von Gunten, U., Kinetics and mechanisms of formation of bromophenols during drinking water chlorination: Assessment of taste and odor development. Water Res 2005, 39, (13), 2979-2993.

(45) Gallard, H.; Pellizzari, F.; Croué, J. P.; Legube, B., Rate constants of reactions of bromine with phenols in aqueous solution. Water Res 2003, 37, (12), 2883-2892.

(46) Tee, O. S.; Paventi, M.; Bennett, J. M., Kinetics and mechanism of the bromination of phenols and phenoxide ions in aqueous solution. Diffusion-controlled rates. J Am Chem Soc 1989, 111, (6), 2233-2240.

(47) Guo, G.; Lin, F., The bromination kinetics of phenolic compounds in aqueous solution. J Hazard Mater 2009, 170, (2-3), 645-651.

(48) Criquet, J.; Rodriguez, E. M.; Allard, S.; Wellauer, S.; Salhi, E.; Joll, C.; von Gunten, U., Reaction of bromine and chlorine with phenolic compounds and natural organic matter extracts electrophilic aromatic substitution and oxidation. Water Res 2015, http://dx.doi.org/10.1016/j.watres.2015.08.051.

(49) Gallard, H.; Von Gunten, U., Chlorination of phenols: Kinetics and formation of chloroform. Environ Sci Technol 2002, 36, (5), 884-890.

(50) Dickenson, E. R. V.; Summers, R. S.; Croue, J. P.; Gallard, H., Haloacetic acid and trihalomethane formation from the chlorination and bromination of aliphatic beta-dicarbonyl acid model compounds. Environ Sci Technol 2008, 42, (9), 3226-3233.

(51) Arnold, W. A.; Bolotin, J.; von Gunten, U.; Hofstetter, T. B., Evaluation of functional groups responsible for chloroform formation during water chlorination using compound specific isotope analysis. Environ Sci Technol 2008, 42, (21), 7778-7785.

(52) Criquet, J.; Rodriguez, E. M.; Allard, S.; Wellauer, S.; Salhi, E.; Joll, C. A.; von Gunten, U., Reaction of bromine and chlorine with phenolic compounds and natural organic matter extracts Electrophilic aromatic substitution and oxidation. Water Res 2015, 85, 476-486.

(53) von Gunten, U., Ozonation of drinkingwater: part II. disinfection and by-product formation in presence of bromide, iodide or chlorine. Water Res. 2003, 37, 1469-1487.

(54) Richardson, S. D.; Fasano, F.; Ellington, J. J.; Crumley, F. G.; Buettner, K. M.; Evans, J. J.; Blount, B. C.; Silva, L. K.; Waite, T. J.; Luther, G. W.; McKague, A. B.; Miltner, R. J.; Wagner, E. D.; Plewa, M. J., Occurrence and mammalian cell toxicity of iodinated disinfection byproducts in drinking water. Environ Sci Technol 2008, 42, (22), 8330-8338.

(55) Agus, E.; Voutchkov, N.; Sedlak, D. L., Disinfection by-products and their potential impact on the quality of water produced by desalination systems: A literature review. Desalination 2009, 237, (1-3), 214-237.

(56) Kim, D.; Amy, G. L.; Karanfil, T., Disinfection by-product formation during seawater desalination: A review. Water Res 2015, 81, (0), 343-355.

(57) Magazinovic, R. S.; Nicholson, B. C.; Mulcahy, D. E.; Davey, D. E., Bromide levels in natural waters: its relationship to levels of both chloride and total dissolved solids and the implications for water treatment. Chemosphere 2004, 57, (4), 329-335. 
Figure 1 Effect of $\mathrm{CuO}$ dose on (a) residual oxidant and formed $\mathrm{BrO}_{3}{ }^{-}$, (b) THMs and (c) HAAs. Experimental conditions: $[\mathrm{HOCl}]_{0}=40 \mu \mathrm{M},\left[\mathrm{Br}^{-}\right]_{0}=10 \mu \mathrm{M},[\mathrm{DOM}]=2.5 \mathrm{mg} \mathrm{L}^{-1},[\mathrm{CuO}]=0-0.2$ $\mathrm{g} \mathrm{L}^{-1}, \mathrm{pH}=8.6, \mathrm{~T}=21 \pm 1^{\circ} \mathrm{C}$, reaction time $=2 \mathrm{~h}$.

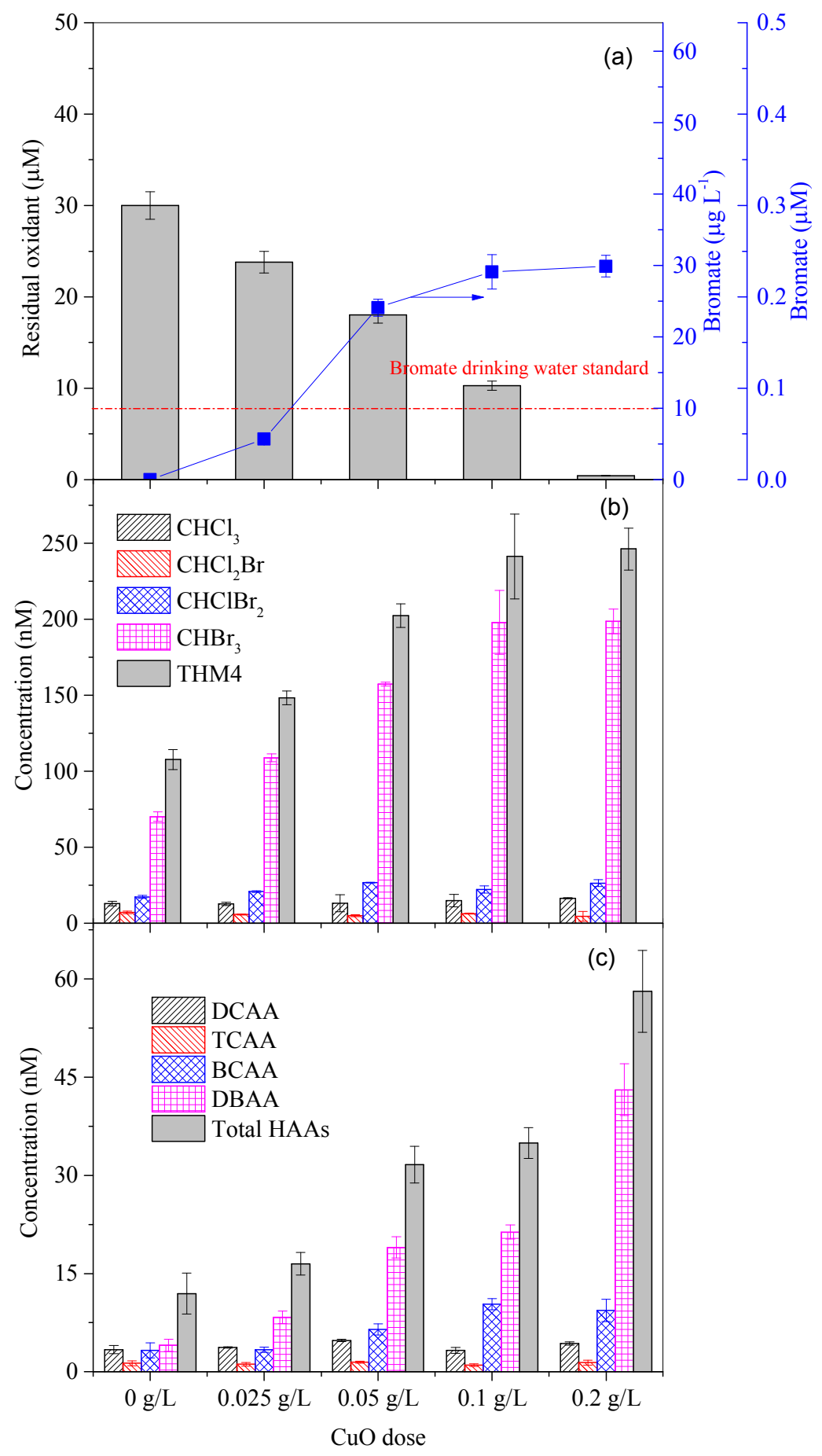


Figure 2 Effect of initial chlorine concentration on (a) residual oxidant and formed $\mathrm{BrO}_{3}^{-}$, (b) THMs and (c) HAAs. Experimental conditions: $[\mathrm{HOCl}]_{0}=14-70 \mu \mathrm{M},\left[\mathrm{Br}^{-}\right]_{0}=10 \mu \mathrm{M},[\mathrm{DOM}]=$ $2.5 \mathrm{mg} \mathrm{L}^{-1},[\mathrm{CuO}]=0.025 \mathrm{~g} \mathrm{~L}^{-1}, \mathrm{pH}=8.6, \mathrm{~T}=21 \pm 1{ }^{\circ} \mathrm{C}$, reaction time $=8 \mathrm{~h}$.

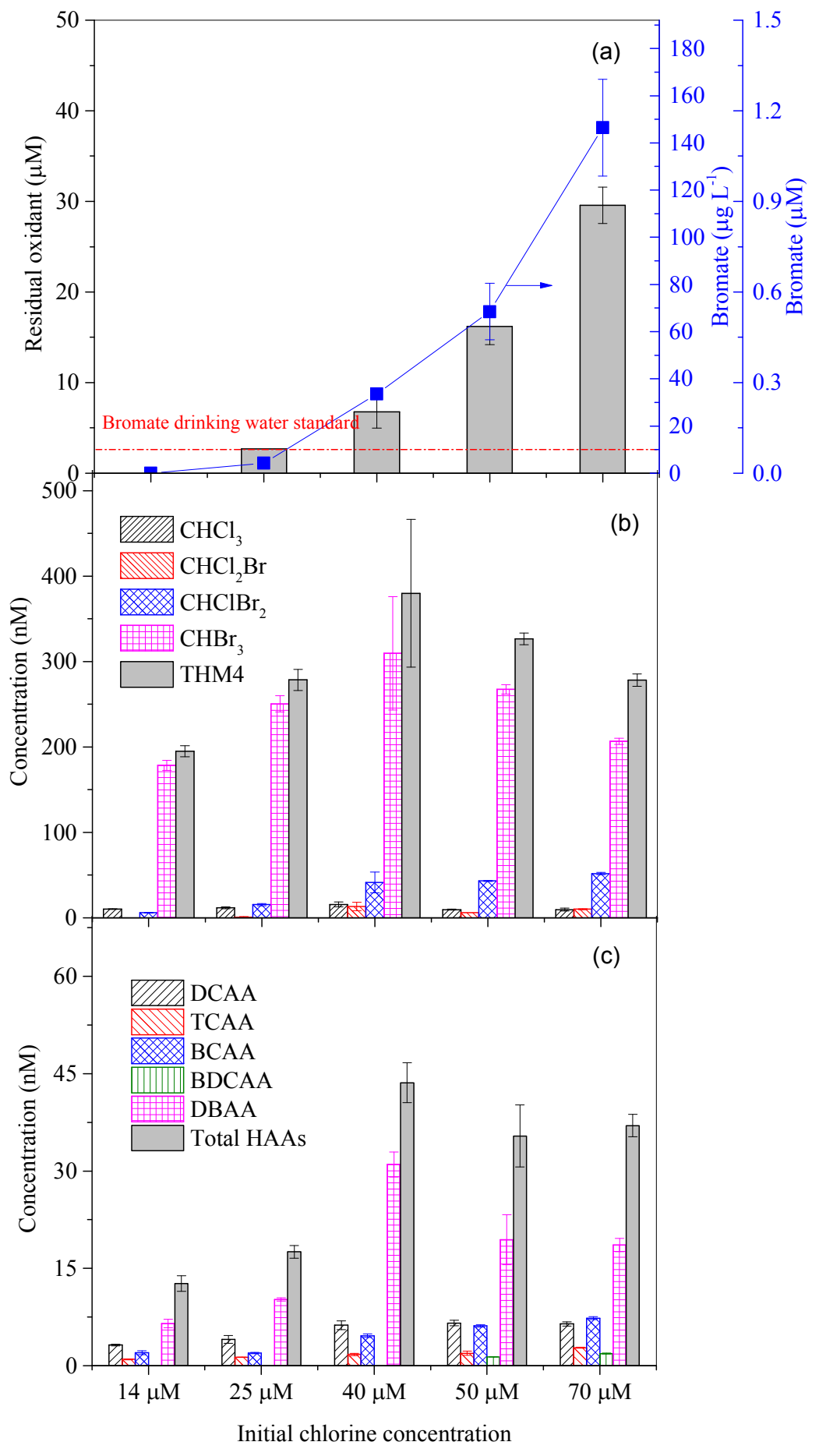


Figure 3 Effect of $\mathrm{pH}$ on (a) residual oxidant and formed $\mathrm{BrO}_{3}^{-}$, (b) THMs and (c) HAAs. Experimental conditions: $[\mathrm{HOCl}]_{0}=40 \mu \mathrm{M},\left[\mathrm{Br}^{-}\right]_{0}=10 \mu \mathrm{M},[\mathrm{DOM}]=2.5 \mathrm{mg} \mathrm{L} \mathrm{L}^{-1},[\mathrm{CuO}]=$ $0.025 \mathrm{~g} \mathrm{~L}^{-1}, \mathrm{pH}=6.6-9.6, \mathrm{~T}=21 \pm 1^{\circ} \mathrm{C}$, reaction time $=8 \mathrm{~h}$.

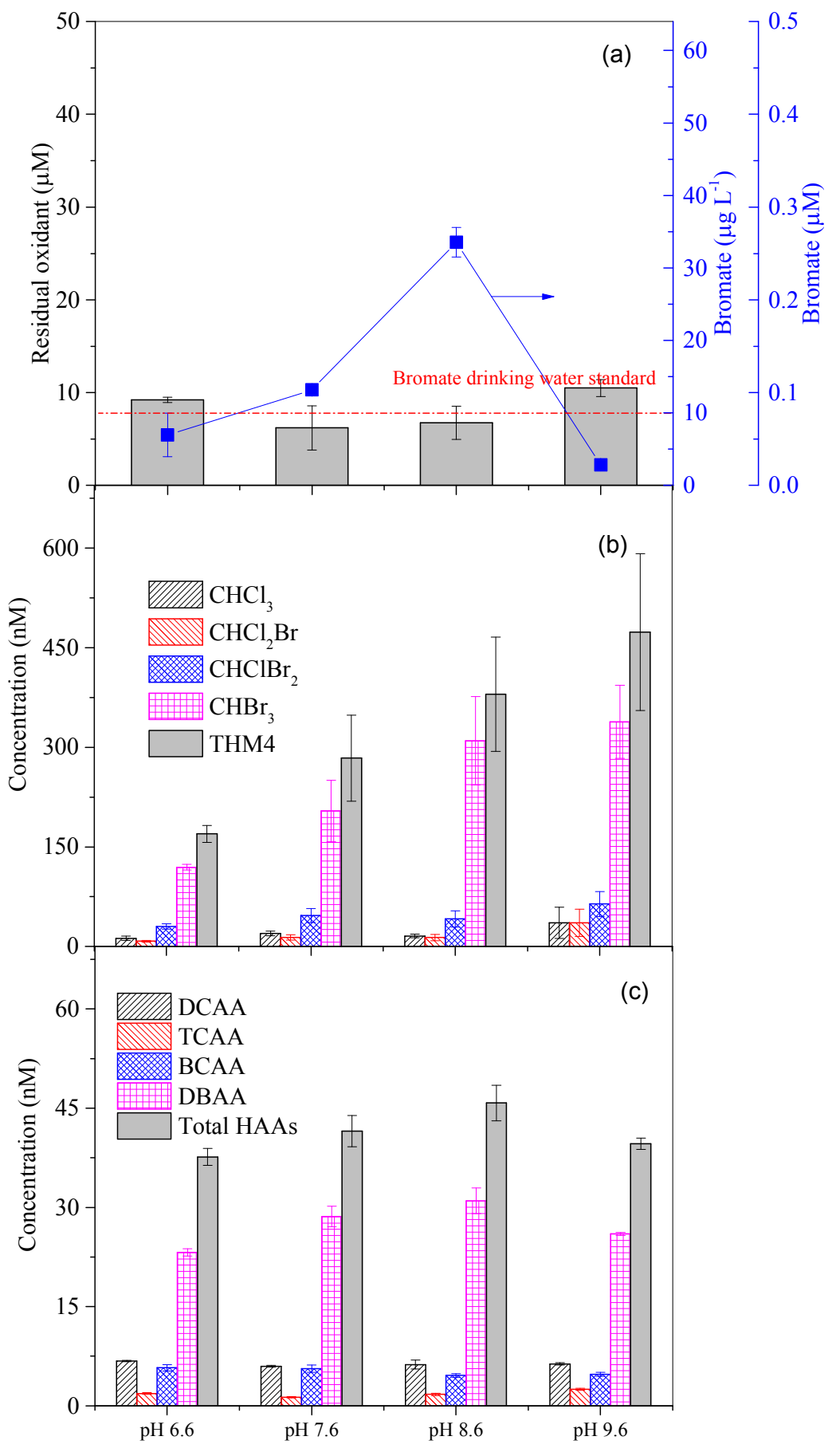


Figure 4 Plot of $\mathrm{SUVA}_{254}$ values vs. (a) THM4 and (b) total HAAs in the absence and presence of $0.1 \mathrm{~g} \mathrm{~L}^{-1} \mathrm{CuO}$. Experimental conditions: $[\mathrm{HOCl}]_{0}=40 \mu \mathrm{M},\left[\mathrm{Br}^{-}\right]_{0}=10 \mu \mathrm{M},[\mathrm{DOC}]=1.3 \mathrm{mg} \mathrm{C}$ $\mathrm{L}^{-1}, \mathrm{pH}=8.6, \mathrm{~T}=21 \pm 1{ }^{\circ} \mathrm{C}$, reaction time $=2 \mathrm{~h}$.

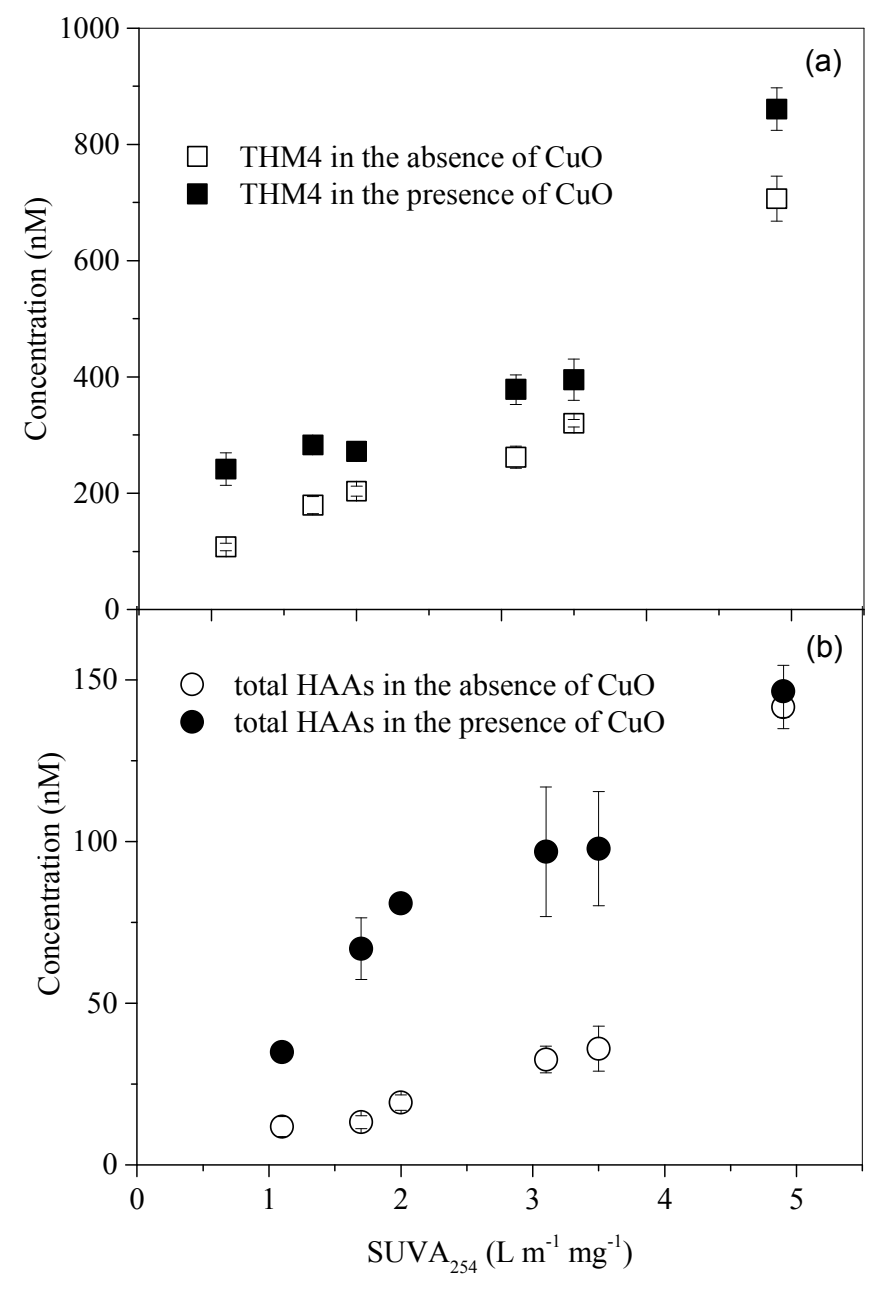


Scheme 1 Potential reactions during chlorination of bromide-containing waters in the presence of dissolved organic matter and $\mathrm{CuO}$. (Solid lines, main pathways; dashed lines, minor pathways.).

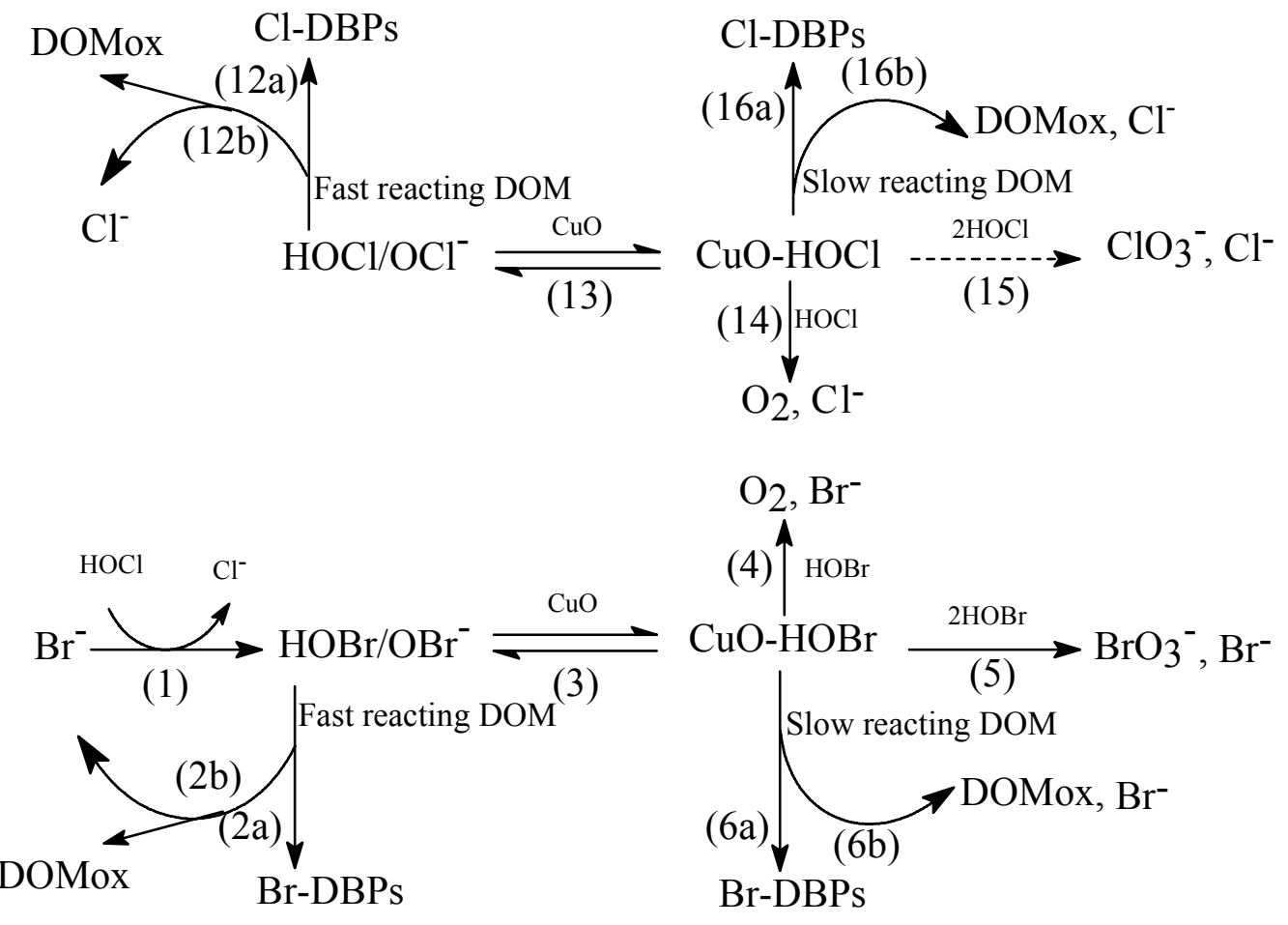


Table 1. Consumption of bromine and formation of byproducts during bromination of model compounds in the absence or presence of $0.1 \mathrm{~g} \mathrm{~L}^{-1} \mathrm{CuO}$

\begin{tabular}{|c|c|c|c|c|c|c|c|c|}
\hline \multirow[t]{2}{*}{ Compounds } & \multicolumn{2}{|c|}{$\begin{array}{c}\text { Consumed bromine } \\
\mu \mathrm{M}\end{array}$} & \multicolumn{2}{|c|}{$\begin{array}{c}\text { Bromate } \\
\mu \mathrm{M}\end{array}$} & \multicolumn{2}{|c|}{$\begin{array}{c}\mathrm{CHBr}_{3} \\
\mathrm{nM}\end{array}$} & \multicolumn{2}{|c|}{$\begin{array}{c}\text { DBAA } \\
\text { nM }\end{array}$} \\
\hline & - & + & - & + & - & + & - & + \\
\hline blank & NA & $40.0 \pm 0.6$ & NA & $10.2 \pm 0.1$ & NA & NA & NA & NA \\
\hline \multicolumn{9}{|c|}{ practically unreactive group } \\
\hline Acetone & $2.3 \pm 0.3$ & $40.8 \pm 0.1$ & ND & $10.1 \pm 0.4$ & $219.4 \pm 4.4$ & $144.2 \pm 6.8$ & ND & $12.3 \pm 1.1$ \\
\hline n-Butanol & $1.9 \pm 0.8$ & $40.2 \pm 0.1$ & ND & $10.3 \pm 0.1$ & $12.9 \pm 0.8$ & $7.3 \pm 0.2$ & ND & $15.0 \pm 0.8$ \\
\hline Propionic acid & $1.7 \pm 1.2$ & $40.3 \pm 0.4$ & ND & $10.2 \pm 0.1$ & $3.3 \pm 0.2$ & $5.7 \pm 0.2$ & ND & $9.1 \pm 2.1$ \\
\hline $\begin{array}{l}\text { Butyric acid } \\
\text { slow reacting gr }\end{array}$ & $\begin{array}{l}1.7 \pm 0.1 \\
\text { oup }\end{array}$ & $39.9 \pm 0.1$ & ND & $10.3 \pm 0.1$ & $2.2 \pm 0.2$ & $8.9 \pm 1.1$ & ND & $12.9 \pm 0.8$ \\
\hline Oxalic acid & $1.6 \pm 0.5$ & $47.3 \pm 0.8$ & ND & ND & $2.2 \pm 0.3$ & $4.1 \pm 2.1$ & $0.9 \pm 0.1$ & $3.1 \pm 1.5$ \\
\hline Malonic acid & $2.0 \pm 0.5$ & $46.6 \pm 0.4$ & ND & ND & $1.6 \pm 0.2$ & $178.1 \pm 61.8$ & $2.2 \pm 0.1$ & $48.8 \pm 16.8$ \\
\hline Succinic acid & $1.8 \pm 0.8$ & $48.8 \pm 0.5$ & ND & $1.5 \pm 0.1$ & $4.2 \pm 0.3$ & $291.6 \pm 49.5$ & $1.6 \pm 0.4$ & $156.0 \pm 44.7$ \\
\hline $\begin{array}{l}\text { Citric acid } \\
\text { fast reacting } \mathrm{g}\end{array}$ & up $3.4 \pm 0.8$ & $49.5 \pm 0.1$ & ND & 0.2 & $375.7 \pm 36.7$ & $8713.8 \pm 1821.0$ & $31.6 \pm 6.8$ & $1912.7 \pm 154.0$ \\
\hline Phenol & $49.6 \pm 0.1$ & $49.6 \pm 0.1$ & ND & ND & $49.1 \pm 2.3$ & $31.5 \pm 1.0$ & $1.6 \pm 0.3$ & $1.2 \pm 0.2$ \\
\hline Hydroquinone & $42.1 \pm 0.2$ & $43.5 \pm 0.3$ & ND & ND & $10.2 \pm 0.6$ & $18.3 \pm 0.6$ & $2.3 \pm 0.4$ & $2.3 \pm 1.0$ \\
\hline Catechol & $49.2 \pm 0.1$ & $48.9 \pm 0.1$ & ND & ND & $2.0 \pm 0.1$ & $1.3 \pm 0.2$ & $1.0 \pm 0.2$ & $1.1 \pm 0.2$ \\
\hline Resorcinol & $49.6 \pm 0.1$ & $49.6 \pm 0.1$ & ND & ND & $6367.5 \pm 35.0$ & $5357.5 \pm 103.8$ & $7.1 \pm 0.9$ & $7.8 \pm 0.3$ \\
\hline
\end{tabular}

Experimental conditions: $[\mathrm{HOBr}]_{0}=50 \mu \mathrm{M},[\text { model compound }]_{0}=50 \mu \mathrm{M}, \mathrm{pH}=8.6, \mathrm{~T}=21 \pm 1{ }^{\circ} \mathrm{C}$, reaction time $=2 \mathrm{~h}$. -: In the absence of $\mathrm{CuO} ;+$ : In the presence of $\mathrm{CuO}$. NA: not available, ND: not detected. 


\section{TOC ART}

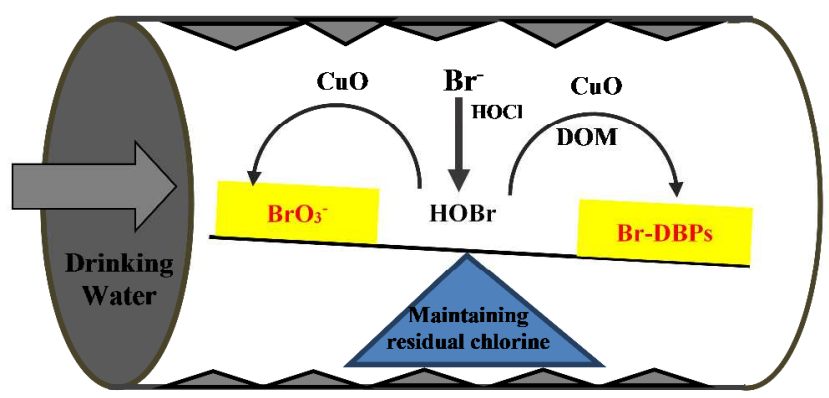

